\title{
Preference of Use of Transportation Mode in Travelling
}

\author{
Deky Aji Suseno $^{1}$, Nur Aisah ${ }^{2}$ \\ \{dekyajisuseno@mail.unnes.ac.id ${ }^{1}$ \} \\ Universitas Negeri Semarang, Indonesia ${ }^{1,2}$
}

\begin{abstract}
Mode of transportation facilities have an important role for the development of the tourism sector. However, there are several regions in Central Java, not showing this. There are some regions that have more complete modes of transportation facilities and a greater number compared to other regions, but do not have as many tourist arrivals as other areas with fewer facilities. The guess is that there is a preference for certain modes of transportation in traveling to tourist attractions. Therefore, it is necessary to study how individual preferences in using modes of transportation in traveling in Central Java. The objective of this study is to identify and analyze individual preferences in using modes of transportation when traveling in Central Java. The analytical method used is the mix method, which is a combination of qualitative analysis and quantitative analysis. In detail, the analytical method used is the Analysis Hierarchy Process and Descriptive Analysis. Analysis Hierarchy Process is used to obtain preference for the use of transportation modes. Descriptive analysis is used to describe, explain and reinforce the results of the Analysis Hierarchy Process. The results obtained priority scale of preference in the use of transportation modes in traveling. Furthermore, there are criteria that serve as reasons for choosing transportation modes. Then the criteria are known to be the priority of individuals in a tour.
\end{abstract}

Keywords: Modes of Transportation, Individual Preference, Analysis Hierarchy Process, Priority Scale, Traveling

\section{Introduction}

The tourism industry has an important role, because it can increase economic growth, the country's foreign exchange, and employment, which ultimately can reduce inequality of individual income and between regions. The size of the tourism industry's income is influenced by the number of tourist visits.

Tourist arrivals to Indonesia experienced an upward trend in 2015-2018, both for foreign and domestic tourists. The following Table 1 shows the target and realization of the number of tourist visits to Indonesia during 2015-2018.

Table 1. Targets and Realization of the Number of Tourist Visits to Indonesia 2015-2018

\begin{tabular}{|c|c|c|c|c|c|c|c|c|}
\hline \multicolumn{1}{|c|}{ (in Million People) } \\
\cline { 2 - 9 } Indicators & Targets & Realization & Targets & Realization & Targets & Realization & Targets & Realization \\
\hline $\begin{array}{c}\text { Foreign Tourists } \\
\text { (in Million } \\
\text { Visits) }\end{array}$ & 10 & 10.41 & 12 & 12.02 & 15 & 14.04 & 17 & 15.81 \\
\hline
\end{tabular}




\begin{tabular}{|c|c|c|c|c|c|c|c|c|}
\hline $\begin{array}{c}\text { Nusantara } \\
\text { Tourists (in } \\
\text { Million Travel) }\end{array}$ & 255 & 256.42 & 260 & 264.33 & 265 & 270.82 & 270 & 303.5 \\
\hline
\end{tabular}

Source: Ministry of Tourism, 2018.

Table 1 shows that the number of foreign and domestic tourists has an upward trend. However, in 2017 and 2018 the number of foreign tourists did not reach the target. The underachievement of targets can be caused by several factors, one of which is a supporting transportation system or facility. This is as stated by Seetanah [1], that the mode of transportation has contributed positively to the number of tourist arrivals in the short and long term.

Transport facilities and tourist visits should have a positive relationship, but in Central Java there are variations in the relationship data. There are cities with a small number of transport infrastructure facilities, but the number of tourist visits is more than cities that have more transportation infrastructure. Table 2 shows the number of transportation infrastructure and the number of tourists in the regencies/ cities in Central Java in 2018.

Table 2. Total Transportation Infrastructure and Tourist in Central Java in 2018

\begin{tabular}{|c|c|c|c|c|c|c|}
\hline \multirow{2}{*}{ District/City } & \multicolumn{4}{|c|}{ Total Transportation Mode Infrastructure } & \multirow{2}{*}{$\begin{array}{c}\text { Amount of } \\
\text { Infrastructure }\end{array}$} & \multirow{2}{*}{$\begin{array}{c}\text { Number of } \\
\text { Tourists }\end{array}$} \\
\hline & Airport & Harbor & Bus Station & Train Station & & \\
\hline Banjarnegara District & & & 1 & & 1 & $1,174,912$ \\
\hline Banyumas District & & & & 9 & 9 & $1,243,468$ \\
\hline Batang District & & 1 & 1 & 5 & 7 & 582,904 \\
\hline Blora District & 1 & & 1 & 5 & 7 & 322,652 \\
\hline Boyolali District & & & 1 & 1 & 2 & 393,746 \\
\hline Brebes District & & 1 & 2 & 9 & 12 & 473,996 \\
\hline Cilacap District & 1 & 1 & & 18 & 20 & 460,960 \\
\hline Demak District & & & 1 & & 1 & $1,619,647$ \\
\hline Grobogan District & & & 1 & 16 & 17 & 565,940 \\
\hline Jepara District & 1 & 2 & & & 3 & $2,583,242$ \\
\hline Karanganyar District & & & 2 & 2 & 4 & 885,311 \\
\hline Kebumen District & & & & 8 & 8 & $1,705,930$ \\
\hline Kendal District & & & & 3 & 3 & $1,176,938$ \\
\hline Klaten District & & & & 5 & 5 & $2,521,992$ \\
\hline Kudus District & & & & & 0 & $1,948,527$ \\
\hline Magelang District & & & 1 & & 1 & $4,971,795$ \\
\hline Magelang City & & & & & 0 & $1,108,142$ \\
\hline Pati District & & 1 & & & 1 & $1,246,791$ \\
\hline Pekalongan District & & & 1 & 2 & 3 & 543,283 \\
\hline Pekalongan City & & 1 & & & 1 & 344,329 \\
\hline Pemalang District & & & & 3 & 3 & 563,637 \\
\hline Purbalingga District & 1 & & 1 & & 2 & $3,799,011$ \\
\hline Purworejo District & & & 2 & 3 & 5 & $1,227,727$ \\
\hline Rembang District & & 1 & & & 1 & $1,530,775$ \\
\hline Salatiga City & & & & & 0 & 106,347 \\
\hline Semarang District & & & & & 0 & $3,042,482$ \\
\hline Semarang City & 1 & 1 & 1 & 6 & 9 & $5,769,389$ \\
\hline Sragen District & & & 1 & 6 & 7 & 367,495 \\
\hline Sukoharjo District & & & 2 & 2 & 4 & 51,949 \\
\hline Surakarta City & 1 & & & 4 & 5 & $3,165,241$ \\
\hline
\end{tabular}




\begin{tabular}{|l|c|c|c|c|c|c|}
\hline Tegal District & & & & 7 & 7 & $1,368,383$ \\
\hline Tegal City & & 1 & & 2 & 3 & 498,884 \\
\hline Temanggung District & & & 1 & & 1 & 539,485 \\
\hline Wonogiri District & & & 4 & 1 & 5 & 403,376 \\
\hline Wonosobo District & \multicolumn{5}{|c|}{ Total Transportation Mode Infrastructure } & $\begin{array}{c}\text { Amount of } \\
\text { District/City }\end{array}$ \\
\cline { 2 - 5 } & Airport & Harbor & Bus Station & Train Station & Infrastructure & $\begin{array}{c}\text { Number of } \\
\text { Tourists }\end{array}$ \\
\hline Total & $\mathbf{6}$ & $\mathbf{1 0}$ & $\mathbf{2 4}$ & $\mathbf{1 1 7}$ & $\mathbf{1 5 7}$ & $\mathbf{4 9 , 6 2 0 , 7 7 5}$ \\
\hline
\end{tabular}

Source: Data processed from Central Java Province Transportation Agency and Central Java Tourism Statistics (2018).

The data shows a condition in which districts/cities in Central Java that have more transportation facilities do not necessarily have more tourist visits. Therefore, there is a suspicion that there is a preference of tourists for certain modes of transportation in conducting tourist visits to an area in Central Java. This paper aims to identify tourist preferences in using modes of transportation in conducting tourist visits in Central Java.

According to RI Law No. 10 of 2009 , tourists are people who travel. Tourism is a variety of tourism activities and is supported by various facilities and services provided by the community, business people, and the government, and local governments. Tourism can be interpreted as an activity of traveling a person or group of people in traveling to areas outside their place of residence for the purpose not to work or find work. AJ Burkart and S. Malik in their book entitled Tourism, Past, Present, and Future, explained that tourism is a temporary and short-term movement of people to destinations outside the place where they usually live and work, and activities their activities while staying at the destination [2].

The type of tourism according to Spillane [3] based on the purpose of the destination tour can be divided into several types of special tourism, namely tourism to enjoy travel (pleasure tourism), tourism for recreation (recreation tourism), tourism for culture (cultural tourism), tourism for sports (sport tourism), tourism for trade businesses (business tourism) and tourism for conventions (convention tourism). Spillane [3] continues that there are five important aspects of tourism, namely attractiveness, facilities needed in tourism (facilities), infrastructure, transportation, and hospitality.

Tourist trips require transportation. Transport is a means to move people or goods from one place or origin to another place or destination, with the intention of helping people or groups of people to reach various places they want, or sending goods from the place of origin to the destination. Passenger public transportation is passenger transportation using public transportation which is carried out using a rental or pay system. Passenger public transportation includes city transportation (bus, minibus, etc.), train and air transportation [4].

Sudiarta [5] said that transportation access can improve tourism development and increase the number of tourists because access to urban areas is becoming smoother and the costs incurred will be cheaper. Geoltom [6] also states that transportation is very important in tourism. So, it can be concluded that access to transportation is also a criterion for tourists in choosing modes/types of transportation in making a tour. Haradongan [7] states that there are several criteria in the selection of transportation modes used, namely fares, travel time, safety, comfort, security and frequency.

Mankiw [8] states that if other things are fixed, then the amount of demand for an item will decrease when the price of the item rises. When this relationship is applied to transportation, the relationship between the goods demanded (modes of transportation) and the price of goods (the cost of using transportation equipment) is inversely proportional. This means that when the 
price of using a mode of transportation increases, the amount of goods demanded (demand for the use of a mode of transportation) will decrease and vice versa.

Thus, it is concluded that there are criteria used in choosing the type/mode of transportation for tourism. These criteria are the price/cost of transportation, travel time, access to transportation, comfort and safety/security.

Types of transportation that are often used to travel in Indonesia and Central Java include trains, buses, private vehicles, ships and airplanes. Gross and Grimm's research [9] shows that $64 \%$ of domestic tourists travel by car, $22 \%$ use e-bike bicycles, $22 \%$ use public transportation, $8 \%$ use cruise ships, $5 \%$ use ferries, and $3 \%$ use trains long distance rail. Research Gutierrez et al. [10] show that tourists who travel in large groups are most likely to use a taxi, while those traveling alone tend to use a private car. Travelers who stayed at hotels exhibited a greater proportion to use taxis or public transport services. In contrast, those who stayed in their own second residences, or with friends or relatives, showed the greatest tendency to use private vehicles for their transfers. This no doubt happened precisely because these were the people with the access to this mode of transport.

Based on this background, it is necessary to further review the factors that are the priority of tourists in making a tour in Central Java. It also sought out modes of transportation which are the choices/preferences of tourists in traveling.

\section{Research Methods}

This research uses primary data types. Primary data used in the form of criteria in the selection of transportation modes and tourist preferences in the selection of transportation modes. Primary data were obtained from respondents and key persons. Key persons consisted of domestic/Nusantara tourists, academics, and people working in the tourism sector. The basis for choosing a keyperson is a person who does, understands and is an expert in travel. Keyperson is taken from 35 districts/cities in Central Java. Each region is represented by one keyperson.

The data collection method of this study is a questionnaire method to obtain and confirm preference data from individuals/users of transportation modes. The questionnaire method was also used to obtain priority scale data which was then processed by the Analysis Hierarchy Process method.

The analytical method used is Descriptive Analysis and Analysis Hierarchy Process. Descriptive analysis methods in the form of activities of grouping, separating, managing, sorting, summarizing data, so they can provide descriptive information that can answer questions from the problem [11]. According to Mason et al. [12], descriptive analysis is used to describe or provide information, which in this research describes the mode of transportation preferences chosen by the user along with the variables on which the choices/preferences are based.

Analysis Hierarchy Process is chosen as the next analysis tool to determine the priority scale of user preferences for the choice of transportation mode based on certain criteria. If the priority scale is known in the selection of transportation modes, then it can be used as a reference in the development of transportation modes to support the tourism sector in an area, especially in Central Java Province. Analysis Hierarchy Process method according to Saaty [13], shows how to determine the priority of elements in a decision problem, by making pairwise comparisons. The scale of pairwise appeals is done in a way that each element is compared in pairs to a specified criterion. Paired comparison scale is used to determine the priority scale of 
criteria chosen by key person in choosing the use of transportation modes in conducting tourism, and to determine alternative priority modes of transportation based on the existing criteria.

\section{Result and Discussion}

The results of the confirmation of respondents, obtained criteria - the basis or reason for them to choose the mode of transportation used in travel. These criteria are cost, time, access, comfort and security/safety. The modes/means of transportation that become an alternative for them to use in tourist trips are trains, buses, private vehicles, ships and airplanes.

Based on the criteria and alternatives obtained, then an Analysis Process Hierarchy framework can be prepared as follows.

Goal
Criteria
Alternative

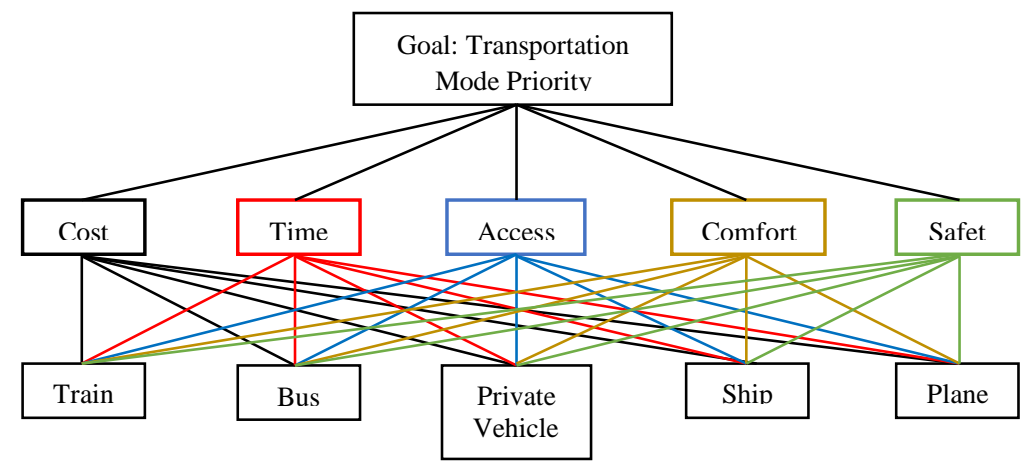

Fig. 1. Analysis Hierarchy Process Framework Source: Primary data, processed.

\subsection{Priority Criteria in Choosing a Mode of Transportation}

Data processing using Expert Choice obtained priority scale criteria that become the basis in the choice of transportation modes in conducting tourist trips. The priority scale of the criteria obtained based on the analysis of pairwise comparison scale data is as follows.

Priorities with respect to:

Combined Goals: Transportation Mode Priority

Comfort
Cost
Safety
Time
Access
Inconsistency $=0.07$
with 0 missing judgments.

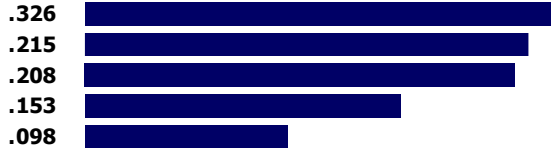

Fig. 2. Criteria Priorities with Respect to Goal. Source: Primary data, processed. 
The results in Figure 2 show that tourists choose comfort as the first priority in choosing the mode of transportation for tourism. The second rank is cost, security is ranked third, time in the fourth and final rank is access to the mode of transportation.

\subsection{Priority Scale of Transportation Based on Comfort Criteria}

Next, we look at the results of data processing when looking at the priority of using modes of transportation to travel if from the standpoint of comfort criteria. The results are shown in Figure 3 as follows.

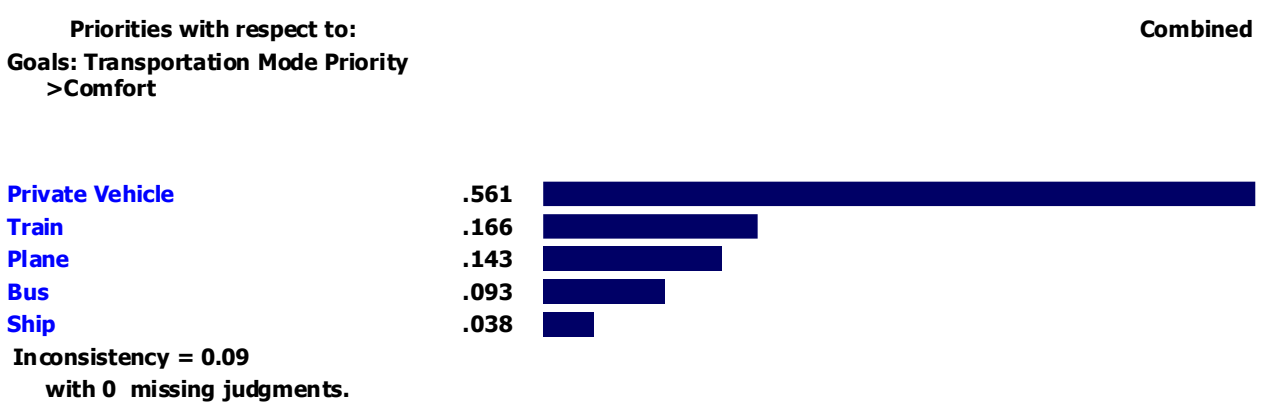

Fig. 3. Transportation Mode Priorities with Respect to Comfort. Source: Primary data, processed.

The priority of choosing the mode of transportation for tourism when viewed from the criteria of comfort is obtained by the private vehicle as the first priority, the train is the second priority, the plane is the third priority, the bus is the fourth priority and the ship is the last priority.

\subsection{Priority Scale of Transportation Mode Based on Cost Criteria}

The priority scale for selecting modes of transportation in conducting tours based on cost criteria, private vehicle is ranked first. Then the bus is ranked second, train is ranked third, plane is ranked fourth and ship is ranked last. In detail, it can be seen in Figure 4 below.

Priorities with respect to:

Combined

Goals: Transportation Mode Priority $>$ Cost

Private Vehicle
Bus
Train
Plane
Ship
Inconsistency $=0.01$
$\quad$ with 0 missing judgments.

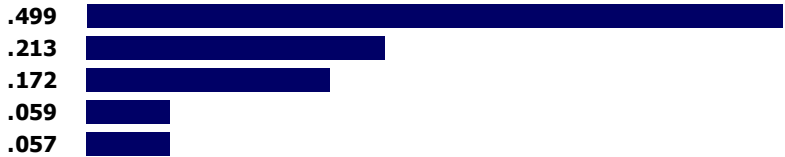

Fig. 4. Transportation Mode Priorities with Respect to Comfort. Source: Primary data, processed. 
Private vehicle was chosen because according to keyperson it has a greater weight compared to other modes of transportation such as buses. The comparison takes into account the large number of people who can take advantage of this mode of transportation and other costs. In accordance with the theory of demand, the cheaper the cost of using the mode of transportation, the more tourists will take advantage of the mode of transportation.

\subsection{Priority Scale of Mode of Transportation Based on Safety Criteria}

The results of data processing based on safety criteria, obtained the priority scale for the selection of transportation modes as follows.

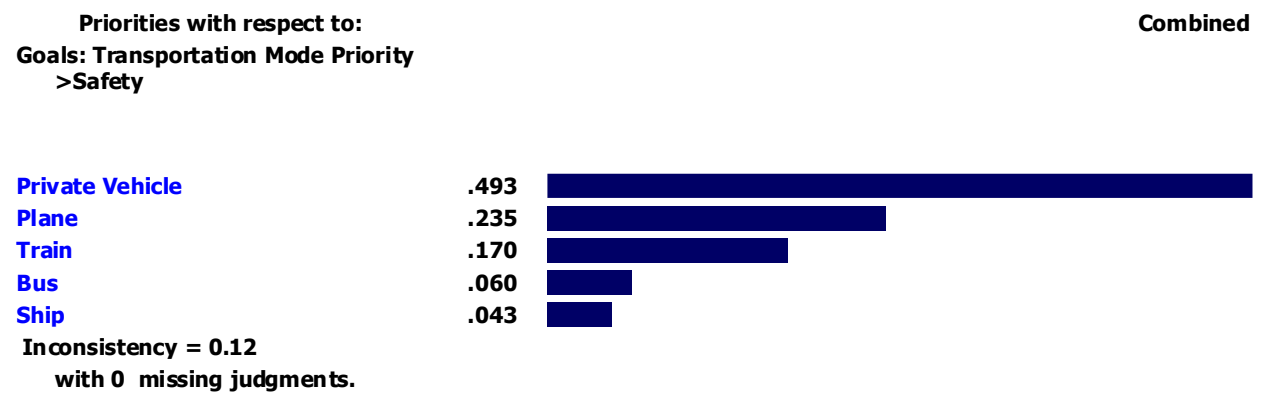

Fig. 5. Transportation Mode Priorities with Respect to Safety.

Source: Primary data, processed.

Based on the results of data processing and as in figure 5, then based on safety criteria, private vehicle becomes the first choice in making a tour. Furthermore, plane on the second priority, train on the third priority, the bus is the fourth priority and the ship is the last priority in making a tour.

\subsection{Priority Scale of Transportation Mode Based on Travel Time Criteria}

The choice of keyperson for transportation modes in conducting travel based on travel time criteria, places the private vehicle in the first priority. The second priority is plane, train is the third priority, bus is ranked fourth, and ship is the last priority when compared to other transportation modes. The ranking of priority scales and the weighting of pairwise comparison scale values in detail can be seen in Figure 6 below. 
Priorities with respect to:

Private Vehicle
Plane
Train
Bus
Ship
Inconsistency $=0.10$
$\quad$ with 0 missing judgments.

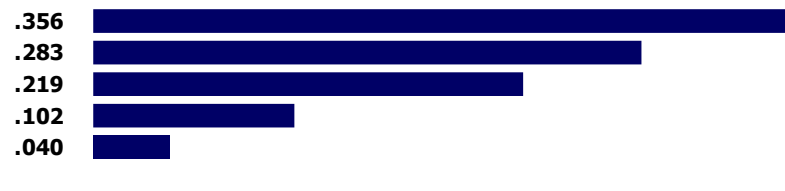

Fig. 6. Transportation Mode Priorities with Respect to Time.

Source: Primary data, processed.

\subsection{Priority Scale of Mode of Transportation Based on Access Criteria}

The choice of transportation mode is based on access criteria, it is found that private vehicle is the first priority. Furthermore, train successively followed by train on the second priority scale, bus in third, plane in fourth position and ship in last position.

Priorities with respect to:

Combined

Goals: Transportation Mode Priority

$>$ Access

Private Vehicle
Train
Bus
Plane
Ship
Inconsistency $=0.07$
$\quad$ with 0 missing judgments.

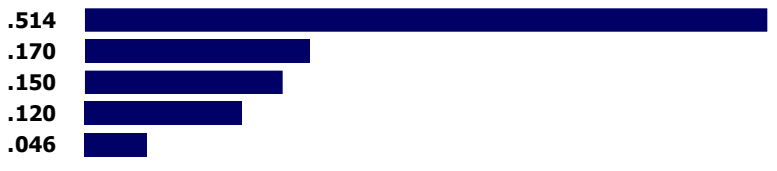

Fig. 7. Transportation Mode Priorities with Respect to Access. Source: Primary data, processed.

The result was caused by the availability of transportation modes in the people of Central Java. Most of the community is easy to access private vehicle transportation modes because many have these modes of transportation. In addition, many private vehicle rentals are also available. As for other types of transportation modes such as train, bus, plane and ship, their existence is very limited. All areas in Central Java have a bus station, but to reach the place is not as easy as a private vehicle. Not all regions in Central Java have train stations, airports and harbor. In accordance with these conditions, it is appropriate if the private vehicle is the first priority scale chosen by tourists in making a tour. 


\subsection{Priority Scale of Mode of Transportation is based on All Criteria}

The results of the selection of transportation modes when considering all the existing criteria, then obtained a private vehicle as the first priority chosen by tourists in making a tour. The second priority after private vehicles is occupied by the train transportation mode. Furthermore, the third priority position is occupied by the plane transportation mode. Buses are the fourth priority, and ship as the last priority based on consideration of all criteria. The details are shown in Figure 8 below.

\section{Synthesis: Summary}

Combined instance .- Sunthesis with respect to: Goals: Transportation Mode Priority

0 verall Inconsistenos $=.07$

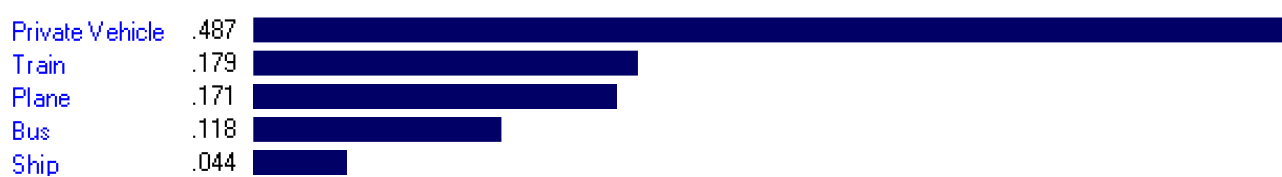

Fig. 8. Synthesis of Transportation Mode Priorities with Respect to all criteria. Source: Primary data, processed.

This result is in accordance with the research by Steg [14] which states that the car is especially more attractive than public transportation because of its convenience, independence, flexibility, comfort, speed, reliability and because driving is perceived to be more pleasurable. The car also offers more status than public transport does. These results also support the study of Gross and Grimm [9] showing that, $64 \%$ of domestic tourists travel by car.

\subsection{Performance Sensitivity of Criteria in Transportation Mode}

Clarifying the scale of priority modes of transportation which are the preferences of tourists in making a tour, then seen how the Performance Sensitivity of criteria in each transportation mode. Sensitivity performance can be used as an approach in sensitivity analysis which is a fundamental concept in the multi-criteria selection method that can be used to measure the stability of the optimal solution selection if there are changes to several parameters. Sensitivity analysis is a common approach and can be done after the calculation process for selecting alternatives to measure the consistency and stability of a calculation result. The results of this sensitivity can be known which criteria are the most critical [15]. The results of performance sensitivity can be seen in Figure 9 below. 


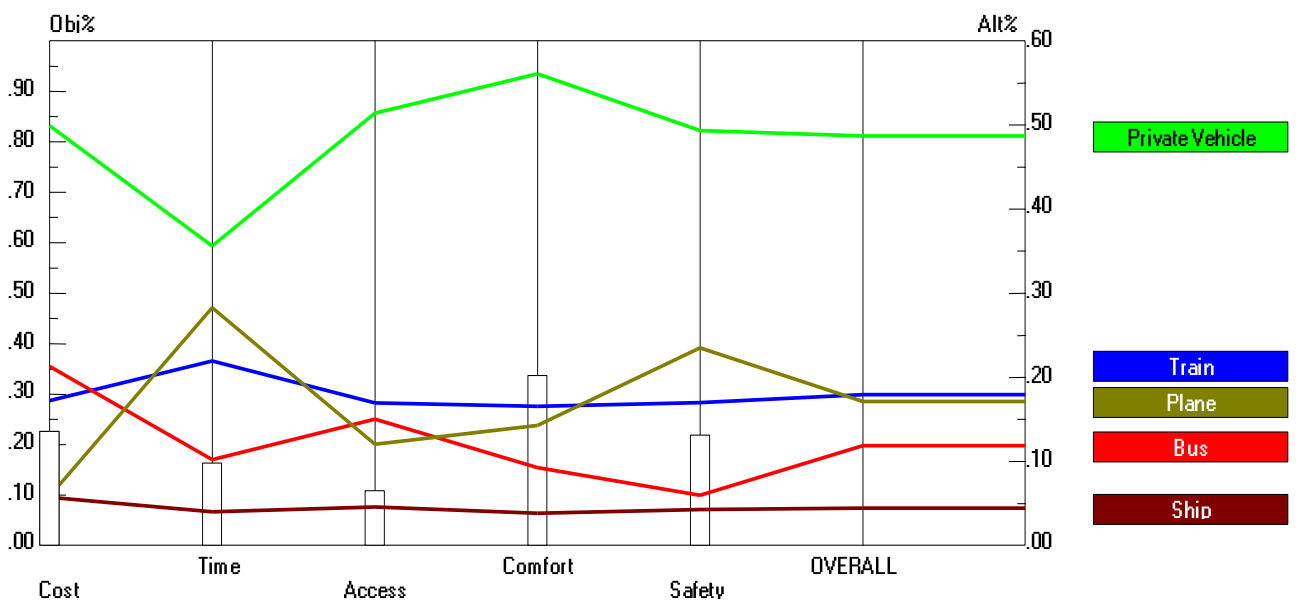

Fig. 9. Performance Sensitivity of Criteria. Source: Primary data, processed.

The value of the sensitivity of the performance criteria based on Figure 9 shows that comfort has the highest value, cost at second place, safety at third place, time at fourth place and access at last place. If seen from its stability, the real stable private vehicle always ranks first on all criteria. While the ship is relatively stable in the selection of all criteria but at the last rank. The train, plane and bus are relatively unstable on all criteria.

\section{Conclusion}

The choice of transportation mode in conducting a tourist trip in Central Java is based on several criteria, namely comfort, safety, cost, time and access. Keypersons choose the comfort factor as the main basis in choosing the mode of transportation in traveling. The alternative modes of transportation that travelers can choose are private vehicles, trains, planes, buses and ships. The transportation mode that is a priority for tourists when they travel is a private vehicle/car, because in terms of low cost, time is also flexible and there is no dependency, access is also easy to obtain.

\section{References}

[1] B. Seetanah and J. Khadaroo, "An analysis of the relationship between transport capital and tourism development in a dynamic framework," Tour. Econ., vol. 15, no. 4, pp. 785-802, 2009.

[2] N. Suarta and G. P. Sudartha, Industri Pariwisata Bali. Depok: PT Rajagrafindo Persada, 2017.

[3] J. J. Spillane, "Indonesian Tourism History and Prospects," Yogyakarta, Canisius, 1987.

[4] S. P. Warpani, Pengelolaan lalu lintas dan angkutan jalan. Penerbit ITB, 2002.

[5] M. Sudiarta, "Dampak Fisik, Ekonomi, Sosial Budaya Terhadap Pembangunan Pariwisata di Desa Serangan Denpasar Bali,” J. Manaj. dan Pariwisata, vol. 4, no. 2, 2012. 
[6] A. D. Geoltom, "Transportasi dan Pariwisata." [Online]. Available: http://file.upi.edu/Direktori/FPIPS/JUR._PEND._GEOGRAFI/197210242001121-

BAGJA_WALUYA/GEOGRAFI_PARIWISATA/Transportasi_dan_Pariwisata.pdf.

[7] F. Haradongan, "Analisis Tingkat Kepentingan Pemilihan Moda Transportasi Dengan Metode Ahp (Studi Kasus: Rute Jakarta-Yogyakarta),” J. Penelit. Transp. Darat, vol. 16, no. 4, pp. 153$160,2014$.

[8] N. G. Mankiw, "Principles of macroeconomics 6th edition," Thompson South-Western Cengage, 2012.

[9] S. Gross and B. Grimm, "Sustainable mode of transport choices at the destination-public transport at German destinations," Tour. Rev., 2018.

[10] A. Gutiérrez, D. Miravet, Ò. Saladié, and S. Anton Clavé, "Transport mode choice by tourists transferring from a peripheral high-Speed Rail station to their destinations: Empirical evidence from Costa Daurada," Sustainability, vol. 11, no. 11, p. 3200, 2019.

[11] M. Kuncoro, "Metode Riset Untuk Bisnis \& Ekonomi, Edisi Keempat,” Jakarta: Erlangga, 2013.

[12] R. D. Mason, D. A. Lind, and W. G. Marchal, "Statistical techniques in business and economics," Irwin/TheMcGraw-Hill Ser. Oper. Decis. Sci., 1999.

[13] T. L. Saaty, "How to make a decision: the analytic hierarchy process," Eur. J. Oper. Res., vol. 48, no. 1 , pp. 9-26, 1990.

[14] S. Linda, "Can public transport compete with the private car?," IATSS Res., vol. 27, no. 2, pp. 27 35, 2003.

[15] S. Widaningsih, "Analisis Sensitivitas Metode AHP Dengan Menggunakan Weighted Sum Model (WSM) Pada Simulasi Pemilihan Investasi Sektor Finansial,” Media J. Inform., vol. 9, no. 1, 2018. 